調查報告＜wide>長期航海における乗船員の精神健康状態

\title{
および疲労感の変動
}

\author{
鎌田豊 彦*, 岩田昇*, 小島豊**

\section{ANALYSES OF NEUROTIC SYMPTOMS AND SUBJECTIVE SYMPTOMS OF FATIGUE OF SEAMEN DURING A LONG VOYAGE}

\author{
Toyohiko Kamada,* Noboru IWATA* and Yutaka KoJIMA**
}

\begin{abstract}
The variations of neurotic symptoms and subjective symptoms of fatigue were studied in relation to circumstances aboard ship in subsamples of the crew $(N=24)$ and students and researchers $(N=24)$ of a training ship belonging to a university during a summer voyage of the North Pacific route in 1987. The data were obtained by a self-administered questionnaire administered seven times before and during the voyage. The present study analysed the data collected during the $40 \mathrm{~d}$ voyage (the first four questionnaires including that before departure).

Complaints of neurotic symptoms and fatigue were reported to be much greater in the present sample than those in a general occupational setting. Although the complaints reported by students and researchers decreased at landing, complaints of physical fatigue reported by the crew increased at landing but those of mental fatigue hardly changed. With regard to correlation between the values of the responses to circumstances aboard ship and the values of neurotic symptoms and fatigue, "quality of sleep" was significantly correlated with these symptoms for the crew. For the students and researchers, significant correlations were demonstrated between such items as "boredom toward work" and "quality of sleep", and physical fatigue, between the "anxiety over disease" and mental fatigue and "anxiety over disease", "risk of injury" and "fear of death" and neurotic symptoms in the first survey after departure (13th day).
\end{abstract}

Key words : fatigue; General Health Questionnaire; job stressor; neurotic symptom; seaman; subjective symptom

\section{I. 緒言}

船上生活には，多くの特殊な潜在的ストレス要因が含 まれている12，船の特性として閉鎖環境状況が長期間に わたって続くため，船内の人間関係は非常に大きな問題 であり2，特に商船などにおいては，船の大型化および 人員削減に伴い，船上生活は生理的にも心理的にも他の

* 産業医科大学産業生態科学研究所人間工学研究室

** 北海道大学大学院環境科学研究科環境医学講座 平成元年 2 月 23 日受付

* Department of Ergonomics, Institute of Industrial Ecological Sciences, University of Occupational and Environmental Health, Japan

** Department of Environmental Medicine, Division of Social Environment, Graduate School of En. vironmertal Science, Hokkaido University Received for publication, February 23, 1989
産業労働に比べて強い人間疎外を示すと報告されてい る32. さらに昨今では外国船員との混乗による摩擦も問 題視されている4).

一方，長期間陸上から隔離されることによるさまざま な制約を指摘されており 5,62 ，特に一般社会や家族から 離れなければならないことは船員の労働と生活およびそ の家庭に大きな影響を及淁していると思われる1,7,8)．

航海海域や季節によっては，らねり等の海況の悪化や 著しい温湿度の変化む少なくなく経験の浅い船員のみな らず，経験豊富な船員にあっても心身の健康状態を乱す 原因となりらる97。海難ないし各種の级害に遭遇するお それるあり，救援態勢が十分ではない海上では病気や怪 我に対する不安は，船員にとって大さなストレッサーと なっている1.

作業環境は、これまでさまざまな改善が施され，格段 
に向上したものの, 船内の騒音と振動は依然として解決 困難な問題である1,10》。これらは, 睡眠の妨害をはじめ 船上生活のさまざまな局面で影響を与えることが推察さ れる、一方, 従来船上では生体りズムを無視した勤務体 制がとられており，概して船員の睡眠や休息は不足しが らである ${ }^{11)}$. 船員の健康状態の不調には労働時間之労働 状態が大きく関係しているとの報告もある12). 実際に船 員の罹患率执よび死亡率は一般集団と比ぺ著しく高いと 報告されている19).

このように労衝負荷の非常に大きな職業であるにもか かからず，船員を対象とした㾂労研究は数少ないのが実 状である. 海外では生理的指標を用いた研究14 18) と質 問紙法を用いた英国，フィンランドでの研究等9,17 19)が 見あたる程度であり，一方日本では，質問紙法による調 查20)ならびに労衝衛生的側面からの研究21 26) が過去に 報告されている.

船員を取り巻く船内状沉は，疲労の直接原因あるいは 背後要因27)といえる．航海の進行とともに変化するその 背後要因ならびに疲労の特徴を経時的に検討することに より, 船内労働負担の様相を把握し，それを基に船員の 労働および生活条件の改善を図ることは重要な課題であ ると思われる.

本研究は，大学練習船を対象に，乗船員の疲労感, 精 神健康状態拉よび船内生活環境諸要因の実態, ならびに それらの関係を航海の推移と共に捉えることを目的とし た調査報告である。

\section{II. 対象および方法}

調査は, 某大学練習船A丸の乗船員 62 名を対象と乙 て，1987 年6月から 74 日間の北太平洋航路往復の間に 行った，調查方法は，多忙な船内業務に支障をきたすこ となく協力を得るため自記式質問紙法を採用した. 62 名 の対象者のうち 54 名より完全回答が得られた（Table 1).このらち職業として船に乗り込んでいる乗組員 (24 名）と普段は陸上で生活を営んでいる学生および水産学 部の教官・大学院生からなる海洋調査員（以下非乗組 員，24名)の 2 群に分けることにした。ただし乗組員の らち司屍員に関しては，その業務が明らかに他の乗組員 の労働様態と異なるため今回解析対象から外した。 対象 者の平均年齢および標準偏差は乗組員で $42.1 \pm 11.8$ 歳 (範囲: $20 \sim 62$ 歳), 非乗組員で $25.8 \pm 7.3$ 歳（範囲： 22〜49墄)であった.

使用した質問票は，船内の疲労に関する背後要因の把 握を目的とする船内状況調查票, 一般健康調査票 (General Health Questionnaire, 以下 $\mathrm{GHQ}$ ), 産衛疲労自
覚症状調べおよび属珄項目として, 年龄・瞕種・乗船年 数 - 婚姻形態 - 持病等から構成されている. 以下に各調 查票の概略を記す。

1) 船内状況調查項目

船上に特有な背後要因として，これまでの報告を参考 にして, 船内環境および生活環境に関する質問項目を設 定した．各項目は 4 つの回答選択肢を持ち，全体で 17 項目よりなっている（付表参照）.

2) 一般健康調查票 $(\mathrm{GHQ})^{28)}$

英米に括いて最も広く用いられている神経症のスクリ ーニングテストであり，健康な状態から神経症圈までの 精神健康状態を測定するものである，GHQ は職域集 団を対象にした研究にも広く用いられており 29 31)，また 邦訳版の妥当性および信頼性もすでに検証されてい る32,333. 60 項目よりなる GHQ には，30，28，20，12 項目の各短濰版があるが，本研究では，最も簡便から欠 損データの頻度が少ない、34,352 12 項目版を用いた。得点 計算は 4 つの回答選択肢に対しおのおの，0-0-1-1 点を 当てはめる $\mathrm{GHQ}$ 得点法を用いた。なお本稿では $\mathrm{GHQ}$ で測定した症状を精神健康状態とする.

3）産衛疲労自覚症状調へ

日本産業告生学会産業疲労研究会 1970 年改編版疲䟫 自覚症状調へ36 393 30 項目のちち, 調査票全体の項目数 の制限により I 群， I群の計 20 項目を用いた。簡略の ため以下の稿においては，「ねむけとたるさ」に関する 疲学感（疲学自覚症状 I 群）を身体的疲労感，「注意集 中の困難」に関する疲労感（疲労自覚症状II群）を精神 的疲労感とする。

本研究では，これらの上記調査票に基づき，船内生活 諸要因のうち，精神健康状態および疲労感に影響を及ぼ している要因を探索することを目的とした.

調查の実施は, 74 日間の航海中, 出港直前 1 週間 (第 1 回目）を含め，出港後 2 週間目（13日目，第 2 回目）, 出港後 1 加月目 (32 日目, 第 3 回目)，1回目の上陸直 後（40日目，第 4 回目)，2回目の寄港直前(49日目） 直後 (58 日目), 航海終了直前 (73 日目) の計 7 回行わ れた。ここでは最も長期間の一連続航海における船内摆 境の影響に注目するため, 出港直前, 13 日目, 32 日目, 40 日目の 4 回分のみ解析を行った。

調查は無記名とし，調査票は全乗船員に対して各調査 地点ごとのそれぞれ夕方配布し当日中に記入することと した．各種調査票は個人の同定を避けるため7回の全闒 查終了まで各個人の管理下においた（留置法）.

解析は, 乗組員群と非乗組員群との比較検討を行引た め, 両群の $\mathrm{GHQ}$ 得点の平均值, 身体的 ·精神的疲労感 


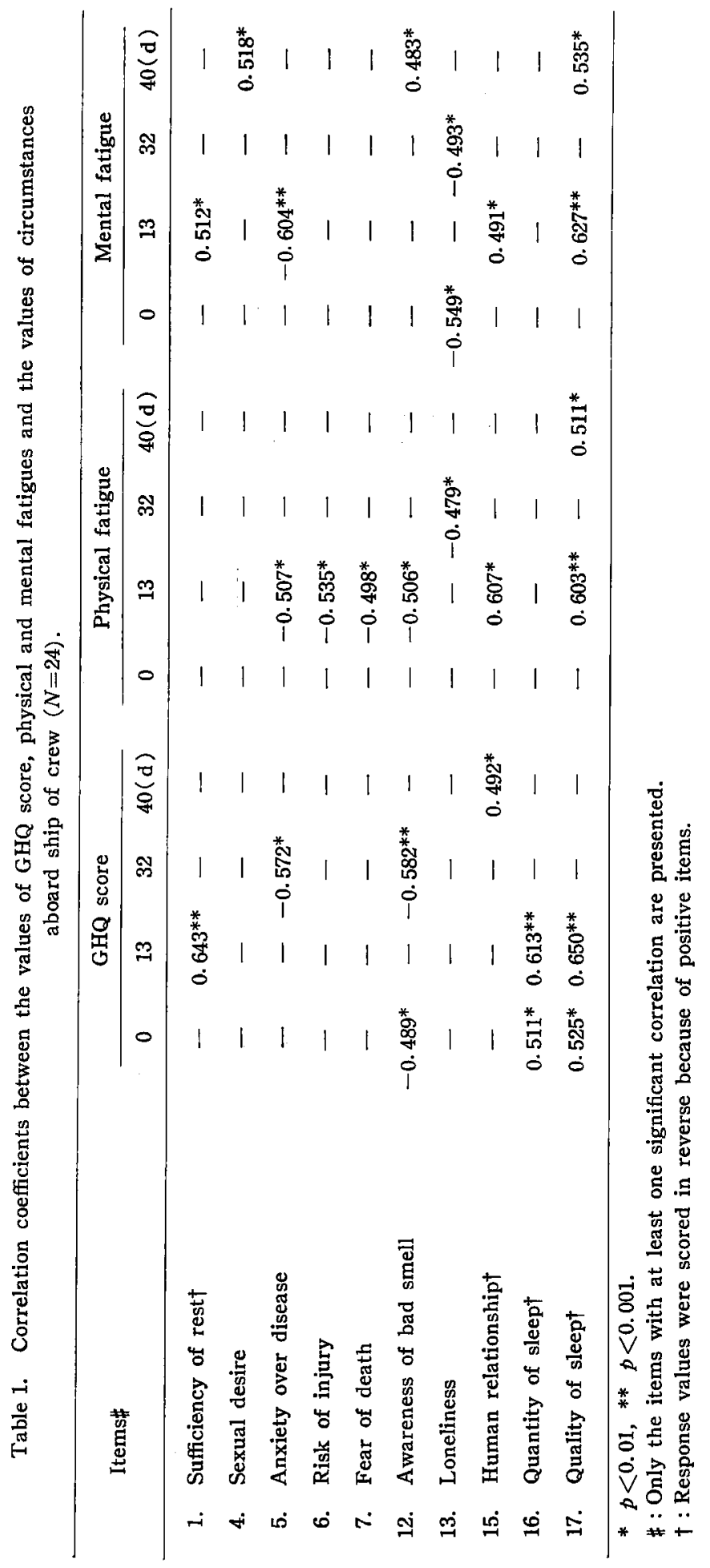




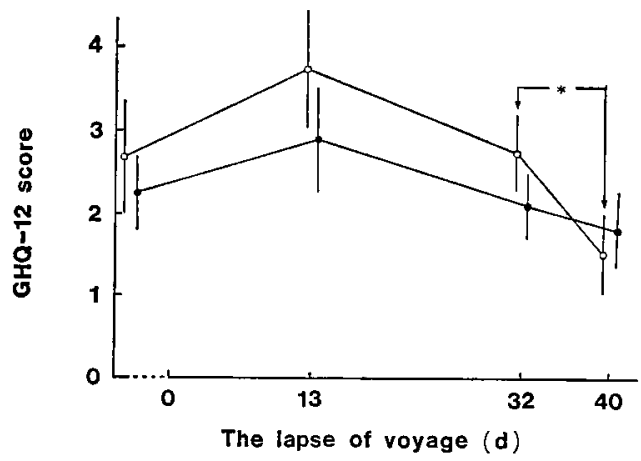

Fig. 1. Mean and S.D. of GHQ-12 score in relation to the lapse of voyage. Crew (-) Noncrew (O). * $p<0.05$.

の有訴率を各調查地点ごとに求め，出港前の測定値を前 值とし，Mann-Whitney のU-test を用い前值と各測定 值との間拉よび各測定值間の差の検定を各群ごとに行っ

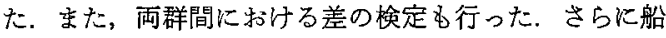
内状沉調查の各項目の值之目的变数である $\mathrm{GHQ}$ 得点, 疲労自覚症状の值の間の相関関保を時間経過とともに順 次検討した。解析には “SPSSx”を用いた。

$$
\text { III. 結 果 }
$$

\section{1. 精神健康状態}

4 回目までの航海における $\mathrm{GHQ}$ 得点の平均值は乗組 員で 2.3, 非乗組貣では 2.7 之両群之も飞非常飞高い値 を示した．GHQ 得点の航海中の推移は Fig.1 に示すご とくである。両群ともに 13 日目の值が最も高くその 後低下した，特に非乘組員の $\mathrm{GHQ}$ 得点は上陸後沉，上 陸前と比較して顕著な低下が認められた $(p<0.05)$. 乗 組員では, 出港前値と各測定值との間拉よび各測定值間 ともに有意の差を示さなかった。

\section{2. 疲労自営症状調查}

\section{1) 身体的疲労感}

平均訴良率は乗組員で $54.5 \%$ ，非乗組員で $37.9 \%$ と ともに非常に高い值を示した，症状項目別では，「目が つかれる」(75.4\%)，「㸚むい」(74.3\%)，「横になりた い」(70.5\%)，「あくびがでる」(55.2\%)，「足がだる い」(54.8\%) の訴えが乗組員で高く，非乗組員では「ね むい」(58.0\%)，「横になりたい」(50.0\%) の訴えが高 値を示した.

経時的に見ると(Fig.2)，両群ともに 32 日目までは同 様の傾向を示したが，上陸後非乗組員では訴方率が低下 し，乗組員では逆に上昇した，各湘定値間の差の検定で は，非乗組員における 13 日目の值が出港前値から有意

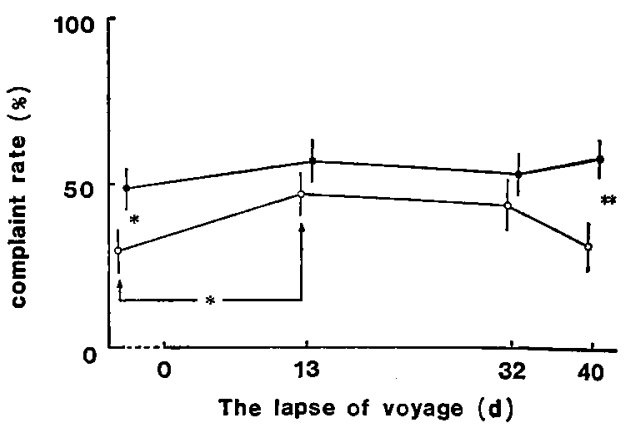

Fig. 2. Mean complaint rate of physical fatigue in relation to the lapse of voyage. Crew $(\bullet)$. Non-crew (O).* $*<0.05, * * p<0.01$.

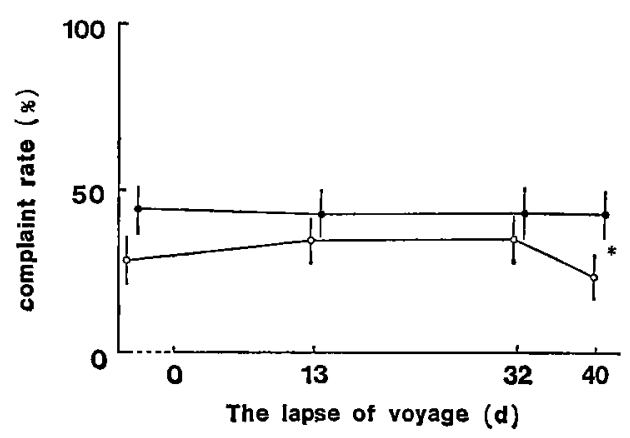

Fig. 3. Mean complaints rate of mental fatigue in relation to the lapse of voyage. $\mathrm{Crew}(\bullet)$. Non-crew (O). * $p<0.05$.

な上昇（ $p<0.05 ）$ を示したのみであった。

2) 精神的疲労感

平均訴光率は乗組員で $43.5 \%$ ，非乗組員で恃 30.8\% とともに非常に高い値を示した．乗組員では，「ちょっ としたことが思い出せない」(70.5\%)，「物事が気仍 かる」(54.2\%) の訴点が高く，一方非烡組員では挀党 率が $50 \%$ を超觉る項目はなかった。

経時的に見ると，乗組員では值が汪とんど变化してい ないが，非乗組員では上陸後に值が低ブする傾向を示し た (Fig.3)。両群とも，出港前値と各測定值との間阽上 び各測定値間ともに有意の盖を示さなかった。

\section{3. 船内状況調查との関係}

船内状海調查の各項目評定値の各湘定点での值と $\mathrm{GHQ}$ 得点および身体的・精神的疲労感の値との相関係

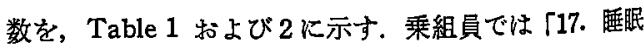
の質」が GHQ 得点および両疲労感と大きな関連を示し た (Table 1). 非乗組員に批いては，13 日目の「5. 病 気への不安」・「6. 怪我への不安」括よび「7. 死の恐怖」 


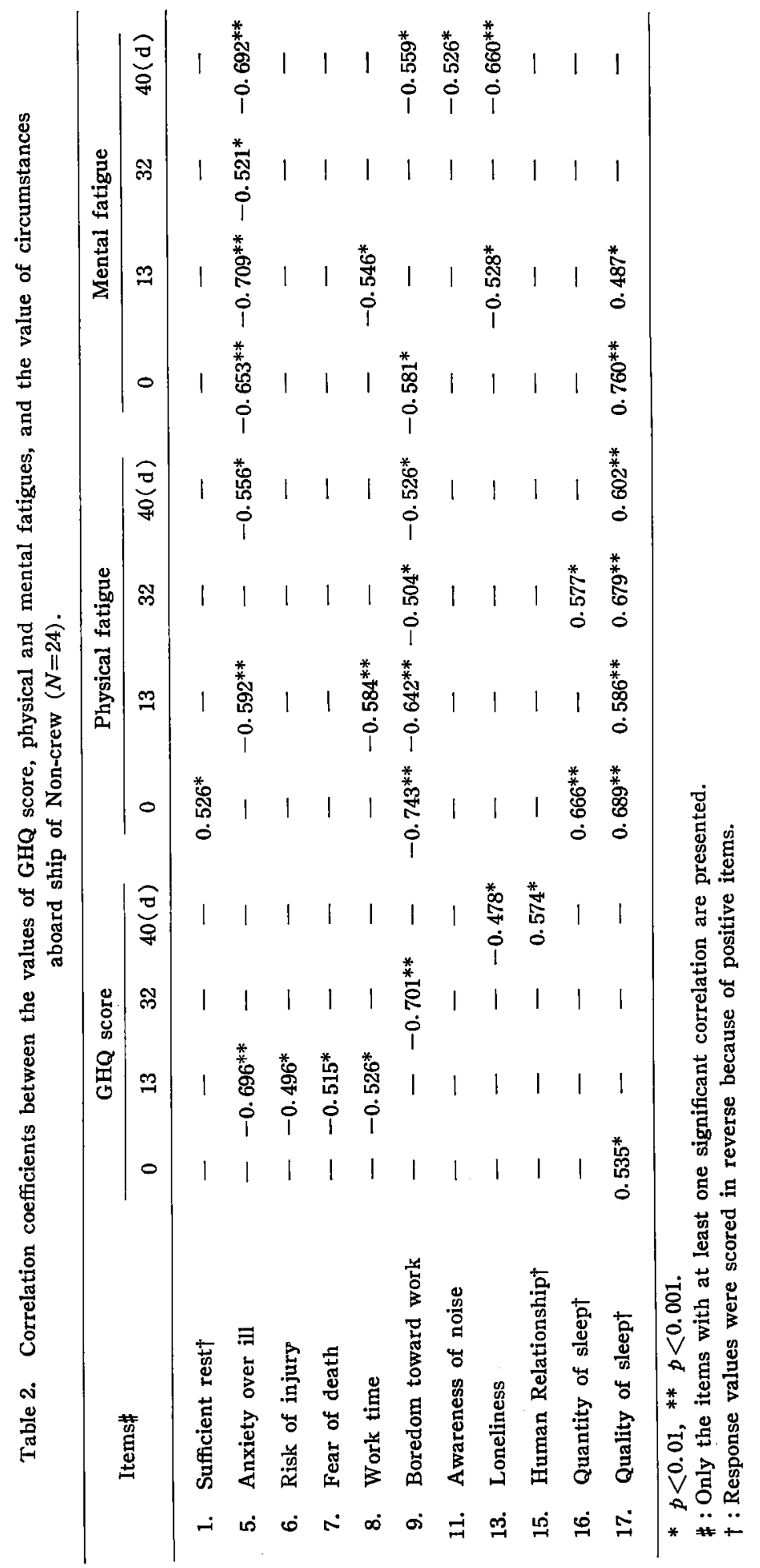


Table 3. Previous researches on Japanese seamen.

\begin{tabular}{|c|c|c|c|c|c|}
\hline 著 者（年） & 対象（人数） & 調查形態 & 調查方法 & 概 & 要 \\
\hline 久我（1963） & $\begin{array}{l}\text { ベルシ+海航路タン } \\
\text { カー }(180 \text { 名 })\end{array}$ & 糈断調查 & 臨床検査 & \multicolumn{2}{|c|}{ 船員の僣总感の原因を探究 } \\
\hline 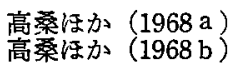 & $\begin{array}{l}\text { 北洋サケマス船 } \\
\text { (3 隻54名) }\end{array}$ & $\begin{array}{l}\text { 横断执よび } \\
\text { 䊈断調査 }\end{array}$ & 労働衛生調查 & \multicolumn{2}{|c|}{ 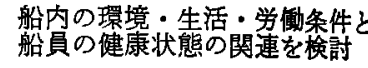 } \\
\hline 小石注（1968） & $\begin{array}{l}\text { 内外䑶商船 } \\
\text { (6 名) }\end{array}$ & 縦断調査 & $\begin{array}{l}\text { 生理·心理機能検 } \\
\text { 孟問紙調睢 }\end{array}$ & \multicolumn{2}{|c|}{ 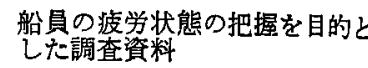 } \\
\hline Nakamura (1973) & $\begin{array}{l}\text { ペルシャ湾航路タン } \\
\text { カー (9隻 } 380 \text { 名) }\end{array}$ & 縦断調査 & 臨床検査 & \multicolumn{2}{|c|}{ 船見の調店状態の把握を目的と } \\
\hline 日高ほか（1980） & 大学練習船（47名） & 絴断調査 & 労働衛生調查 & \multicolumn{2}{|c|}{ 船内環境と生活に関する調査 } \\
\hline 山田（1988） & $\begin{array}{l}\text { 外航船 } \\
\text { (延 }\end{array}$ & 横断調查 & 質問紙調査 & \multicolumn{2}{|c|}{ 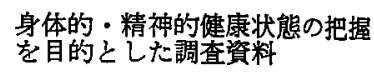 } \\
\hline 本研究 & 大学練習船（54名） & 縦断調查 & 質問紙調查 & \multicolumn{2}{|c|}{ 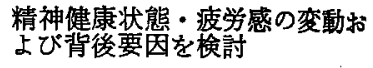 } \\
\hline
\end{tabular}

が GHQ 得点と高い相関を示した「「．労働の飽き」， および「17，睡眠の質」が身体的疲労感と，すべての測 定点で高い相関を示し，「5. 病気への不安」が精神的疲 労感と，すべての測定点で高い相関を示した (Table 2).

\section{IV. 考察}

日本に打ける船員を対象とした調査研究は，これまで 主に労衔衛生的観点から行われたものがほとんどであ $3^{21 \sim 26)}$ (Table 3).

一方, 船員を対象にした心理・社会的研究は他の職域 集団に比してこれまで非常に少ないい，日本に扟ける報 告です，横断的な調査報告がわずかに公刊されている200 のみである.

山田 ${ }^{20}$ は，船員の身体的・精神的健康状態がとも陸 上労働者の有訴率に比へ著しく高いことを報告してい る. 本対象者に和いても，GHQ 得点抎上び疲労自覚症 状の有訴率は，一般勤労集団と比較して常に高値を示し ていたすすなわち，GHQ 得点では乗組員・非乗組員と すに，Iwata らによる日本の一般勤学集団の報告 ${ }^{35)} の$ 1.5 1.8 倍, 英国における Banks らの報告34) の 2 倍 の高値を示した，疲労自覚症状 I 群では, 特に乗組員に おいて一般に高いと言われる夜勱後の有訴率 ${ }^{39}$ 䚾近い值 を示し， I群ではそれ以上の高值を認めた。

本対象がこの上うに高い有訴率を示したのは，船上と いう特殊労(働生活環境下にある20)ことに加之，本船が学 生の航海実習と海洋調查を目的とした練習船であったた ぬ，航海中汪注連日，操業実習および海洋観測が行われ 満足な休息がとれなかったことが影響しているるのと考 完られる.一方，他練習船での疲労自覚症状調査 ${ }^{26)}$ との 比較でも本結果はかなり高い值となっているが，それは
本航海がより長期間であったことおよび調查海域がより 劣悪な気象条件汇曝されていたことが少なからず影響し ているものと推察される.

航海中の变動では，乗組員で上陸後に GHQ 得点将低 下したか，身体的疲労感は逆に增加した．精神的疲学惑 は航海を通して顕著な変化を示さなかった，小石ら29 は，いくつかの商船を対象に行った調查の結果をまと め, 疲労自覚症状が出航後 2 週間ぐらいで聥隇傾向を示 すと報告しているが，本研究ではそのような傾向性認め なかった，一方，非乗組員飞おいて $\mathrm{GHQ}$ 得点，身体 的・精神的疲労感のすべてで 13 日目（第 2 回目）に高 值を示したが，当該調查は，最初の操業（8１3日目)の 最終日にあたって扣り，疲労の蓄積によるものではない かと思われる。32 日目（第 4 回目）飞和祆る $\mathrm{GHQ}$ 得点 の低下は，操業が 5 日前に終了していたこと，鯨の接近 や上陸を直前淕え陸地が見觉るようになったこと等の 状況により，30日目あたりで見られた船内のピリピリし た雰囲気が急激に和やかになったといら対象者集団の実 際の観察結果とは符合する。

出発前扔よび上陸時に打いて両群間に身体的波労感の 差が認められたのは，実際にその時期の労働負荷が非乗 組員に比べて乗組員に高いことを反映しているとも考え られる. また上陸時の精神的疲労感の差は，ほとんどの 乗組員にとっては寄港地が過去に何度となく訪れている 俁楽性のそしい片田舎の漁港でしかないのに対して、非 乗組員にとっては初めて訪れる土地であり，気分転换が 可能であったことの反映かもしれない。

しかしながら，乗組員の疲労感が常に高い値のまま で, 変動幅が少なかった背景には，乗組員の年龄が非乗 組員と比較して高く，疲学の回復が容易でなかっだこと 
む影響していると考学られる．高龄な漁船員に健康状態 の增悪傾向が認められるとの報告22)るある。船員の高龄 化は今後さらに進むと思われるが，船員の度労予防方策 は，ますをす重要な課題となるものと思われる。

船内状況調查項目との関保では，乗組員において，

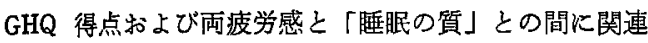
か認められた．また非乗組員では，GHQ 得点は13日目 の「病気への不安」,「怪我への不安」,「死の恐怖」に強 、関連を示しており，精神的疲労感は，GHQ 得点と同 様，「病気への不安」が常に強い関連を認めた。これは 普段の陸上生活と著しく異なる労働・生活環 境の影響 や，万一健康を損なったときの救援態勢に対する不安が

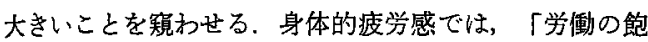
き」「煺眠の質」と関連を認わた。これは船上労働とい 万特殊環境下において, 単調な作業に対する労㖶意欲の 低下と数時間の交替制勤務形態を余儀なく強いられた結 果，睡眼が分断されたことによるもの之考学られる，40 日目の訴党率の低下は，この上らな学働拉よび睡眠不足 状態加開放された結果と考えられる。. Torsvall ら11 は，船における当直制が睡眠と “well-being” 飞影響を 及洔すと報告しているが，本研究に执いてる普段とは全 〈異なる睡眠習慣に突然曝された非乗組員のみならず， 乗組員でる疲労感が睡眠の質と関連したといらことは， 船における睡眠自体に大きな潜在的負担要因があること を示唆しているものと思われる. Eloによる質問紙を用 いての研究報告9では，騒音拉よび海況の变化が船員の ストレス要因としてあげられているが，本調查ではこれ らの項目は特に重要な疲労要因とは認められなかった。 これは設定した質問項目の違いのみならず，前者が横断 的な調查であるのに対して，本研究は航海中の経時的変 化核する梌討を行ったものであるといら方法論上の違 いによるかもしれない。

ところで本研究には調查実施拉よび項目設定に関して いくつかの問題点があげられる。すすなおち前者では，留 直調查法を用いたため, 回答日時が政密化確定できない という点である。また，訓練航海に支障をきたさ奴こと を第一条件として調査日程が組み込をれたため，所要時 間等さまざまな制約により詳細な調査は不可能であっ た. 一方, 出港 1 週間前の回答を航海中の測定值之の比 較炕用いたが，その時期は出港染備でかなり多忙であ ク，通常の状態とは異なる可能性を否定できない，

項目設定の問題としては, 職域集団である乘組員にと $っ て, 今$ 回の船内状洗調查の内容は半ば習慣化した状況 であるため，疲労感等の変動への係わりが希薄である可 能性も否定できない。乗組員のストレス要因に関して
は，社会や家族との分離99，船員の職業意識なども含め た，上り広範で包括的な調查を行う必要があると考え る.

また今回のよらな主観的反応のみならず，かつていく つか報告されているが21 25)，疲学現象に関する生理学 的・生化学的データの蓄皘も今後必要であるう.

\section{V. 結 論}

某大学練習船の北太平洋航路に和ける乗組員 (24 名) 々学生拉よび調查員（24 名）の精神健康状態拉よび疲学 感の変動と船上の疲労に関する背後要因との関連を調へ た. 調查は自記式質問票を用い航海期間中 7 回，留監法 によって行われた。このらち出港直前を含む最初の 4 回 調查分を解析し次の結果を得た。

1）調查対象の両群とむに，一般的な職業集団に比し て高い疲労感を認め，精神健康状態す低いレベルであっ た，特に烡組員の疲労感，学生・調查員の精神健康状態 に沶いてその傾向が顕著であった。

2）乗組員の身体的疲学感は上陸時に訴えが高まり， 精神的疲学感はほとんど变化を認めなかったが，学生・ 調查員では，精神健康状態，身体的・精神的疲労感とも 上陸時枕いて改善された。

3）船内状況調查の各項目の值との関連では，乗組員 では，「睡眠の質」が精神健康状態および両疲労感之高 い相関を示し，学生・調查員では，特に「学働の飽き」・ 「睡眠の質」が身体的疲労感々，「病気への不安」が精 神的疲学感と相関し，13 日目に打いて「病氮への不安」・ 「怪我への不安」「死の恐怖」が精神健康状態と大きく 関連していた.

稿を終わるに臨み，本調査に対して現場で終始惜しみないご 協力を睗りました北海道大学水座学部「战しょろ九」の船長はじ め乗組員の皆様，また本研究の遂行にあたり多大な示祋をいた だきさした北海道大学医学部公衆䓟生学教室, 志渡晃一氏に深 甚なる感碳の意を表します。

本論文は，昭和 62 年度北海道大学大学院賟境科学研究科社会 環境学専攻修士課程論文飞基ういている。なお，本椧文の一部

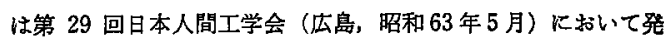
表した. 


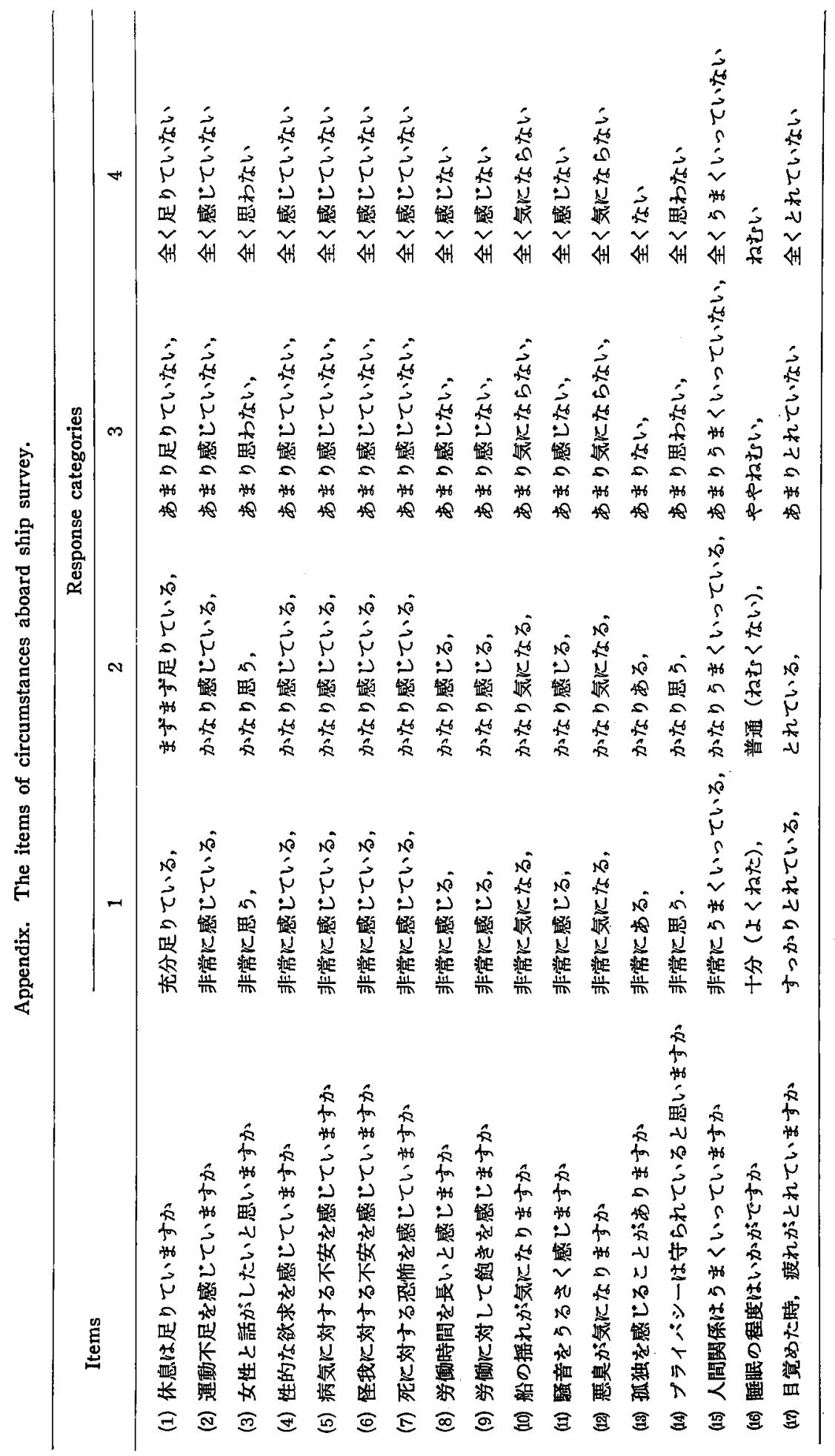




\section{文 献}

1) Sutherland KM, Flin RH. Stress at sea : a review of working conditions in the offshore oil and fishing industries. Work Stress $1989 ; 3: 269-285$.

2) 砸口伸吾. 船員の生活態度に関する調査報告. 海上労伍 調查報告第 1 集. 東京：運榆省船員局， 1949 .

3) 小沼十寸穂. 船内神経症の問題一ことにその拘束性神経 症について. 学働科学 $1977 ; 53: 125-136$.

4）大桥信夫. 労働力の国祭移動之職場に拈ける文化摩擦. 学働科学 $1987 ; 63: 279-298$.

5) Nolan B. A possible perspective on deprivation. In : Frick PH, ed. Seafarer and community. London : Croom Helm Ltd, 1973.

6) Moore SRW. The occupation of trawl fishing and the medical aid available to the Grimsby deep sea fishermen. Br J Ind Med 1969; $26: 1-24$.

7) 神田道子. 船員家族の現状 (第一報). 労(働科学 1963 ; $39: 366-371$.

8）影山隆之. 船員の㤗の保健学的一側面 夫不在々母親の あり方をぐって. 産業医学 1987；29：110-115.

9) Elo AL. Health and stress of seafarers. Scand J Work Environ Health $1985 ; 11: 427-432$.

10) 西部徹一. 海上学働科学のあゆみ(7). 労働の科学 1977; $32: 63-69$.

11) Torsvall $L$, Castenfors $K$, Akerstedt $T$, et al. Sleep at sea : a diary study of the effects of unattended machinery space watch duty. Ergonomics 1987; $30: 1335-1340$.

12) Dolmierski R, Walden $K J$. Environmental factors causing neurosis in seamen. Bull Inst Marit Trop Med Gdynia $1972 ; 23: 7-13$.

13）西部徹一. 海上労働科学のあゆみ(19). 労働の科学 $1978 ; 33: 58-62$.

14) Zorn EW, Harrington JM, Goethe H. Ischemic heart disease and work stress in West German sea pilots. J Occup Med 1977; 19: 762-765.

15) Rodahl K, Vokac Z. The work of physiology of fishing. Psychother Psychosom 1979; 32:52-59.

16) Cook TC, Cashman PMM. Stress and ectopic beats in ships' pilots. J Psychosom Res 1982; 26: 559-569.

17) Matsevitch LM, Poroshenko AS. The influence of the duration of a voyage on the functional state of a seamen's body. Bull Inst Marit Trop Med Gdynia 1974; 25 : 443-446.

18) Filikowski J. Effect of the working environment on ocean-going ships, on the seamen's health. Suggestions concerning prophylaxis indications. Bull Inst Marit Trop Med Gdynia 1977; $28: 5-15$.

19) Cooper CL, Sutherland VJ. Job stress, mental health, and accidents among offshore workers in the oil and gas extraction industries. J Occup Med 1987; 29:119-125.

20) 山田豊簏. 外国航路船舶乘組員 2 CMI 健康調查研究. 名市大医誌 $1988 ； 39: 45-66$.

21）久我正男. ペルシャ湾航路タンカー乗組員の訴える倦意
感について. 労做科学 1963; 39:90-94.

22）高桑栄昖，万波見雅夫，斉藤和雄，ほか，北洋サケ・、 不㴔学の学懒医学的研究 第 1 報 A丸汇関する調查. 産 業医学 $1968 ； 10: 433-437$.

23）高策栄松，方波見雅夫，斉藤和雄，ほか. 北洋サヶ・マ 不鮘労の労的医学的研究 第 2 報 新・旧型漁船の比較を 中心に. 産業医学 1968; 10:497-504.

24）小石泰道, 服部 昭，山岡靖治. 船員に和ける疲労調查 資料. 労旡科学 $1968 ; 44: 42-57$.

25) Nakamura F. Health status of ocean-going oil tanker seamen. Bull Tokyo Med Dent Univ 1973; $20: 221-244$.

26）日高 昇，秋重䘠音，吉村 浩，西田英明. 漁業練習船 鶴洋丸に的ける環境之生活. 航海 $1980 ； 63: 93-98$.

27）橋本邦落. 精神疲労の検查. 人間工学 $1981 ； 17: 107-$ 113.

28) Goldberg DP. The detection of psychiatric illness by questionnaire. Maudsley monograph No. 21. London: Oxford University Press, 1972 (中川I 泰须，訳．第 1 部 質問紙法による精神矣患者の発見一精 神・神経症症状の診断法および評価法. 質問紙法による精 神・神経症症状の把握の理論と臨床応用. 市川：国立精神 衛生研究所モノクラフ, 1982).

29) Jenkins R. Minor psychiatric morbidity in employed men and women and its contribution to sickness absence. Psychol Med 1980; 10:751-757.

30) Iwata N, Okuyama $Y$, Kawakami $Y$, et al. Psychiatric symptoms and related factors in a sample of Japanese workers. Psychol Med 1988; $18: 659-663$.

31) Rahman M. Job stress, satisfaction and mental health of factory workers in Bangladesh. Work Stress $1989 ; 3: 155-162$.

32）中川泰须，大坊郁夫. 第 2 部 日本版一般墱康調查質問紙 法の妥当性と信頼性の険討とこの質問紙法の臨床応用. 中 川泰樹, 編. 質閔紙法による精神・神経症症状の把握の理論 之臨床応用. 市川：国立精神衛生研究所モノグラフ, 1982.

33) Iwata N, Saito K. Relationships of the Todai Health Index to the General Health Questionnaire and the Center for Epidemiologic Studies Depression Scale. Jpn J Hyg 1987; $42: 865-873$.

34) Banks $\mathrm{MH}$, Clegg $\mathrm{CW}$, Jackson $\mathrm{PR}$, et al. The use of the General Health Questionnaire as an indicator of mental health in occupational studies. J Occup Psychol 1980; 53 : 187-194.

35) Iwata N, Okuyama Y, Kawakami Y, et al. The twelve-item General Health Questionnaire among Japanese workers. Environ Sci Hokkaido Univ $1988 ; 11: 1-10$.

36）座業疲労研究会. 産業疲労の「自覚症状しらべ」(1970) についての報告. 労働の科学 1970；25:12-62.

37）齐藤良夫, 小木和孝, 柏木繁男. 疲労自覚症状の類型化 について. 労働科学 $1970 ; 46: 205-224$.

38）小木和孝, 斉藤良夫, 三觜 武. 疲労自覚症状の 3 成分 の妥当性について. 学謿科学 $1970 ; 46: 251-270$.

39）吉竹 博. 産業疲学一自覚症状がらのフブローチー. 東 京: 労働科学研究所, 1975 .

著者への通信先 : 鎌田豊彦，广807 北九州市八幡西区医生ヶ丘 1-1 産業医科大学産業生態科学研 究所人間工学研究室 Reprint requests to Department of Ergonomics, Institute of Industrial Ecological Sciences, University of Occupational and Environmental Health, Japan, 1-1 Iseigaoka, Yahatanishi-ku, Kitakyushu, 807 Japan (T. Kamada) 